М.В.Лукашенко, аспірантка

Навчально-наукового Гуманітарного Інституту НАУ

\title{
МОДЕРНИЙ ТИП СОЦІАЛЬНОСТІ: МІЖ МИНУЛИМ І НАЛЕЖНИМ
}

Початок історії модерну деякі дослідники (Е.Гідденс, З.Бауман та ін.) пов'язують із поступовим вивільненням людей 3 природних і спільнотних меж, коли людина стає перед необхідністю робити вибір власної і колективної долі в умовах економічної і соціокультурної непевності. Модерн звільнив людину від успадкованої соціальної ролі. Як зауважував 3.Бауман, індивідуалізація полягає в перетворенні людської ідентичності із даності в завдання, з відповідальністю за ії результати. Людина тепер має стати тим, ким вона $\epsilon[1,180]$. Ілюстрацією до даної ситуації можуть служити слова Ж.-П.Сартра, що недостатньо народитися буржуа, необхідно ще й прожити життя як буржуа. Межі такої індивідуалізації визначалися певними стандартами класу, до якого необхідно було приєднатися, членство в якому необхідно постійно підтримувати, що і стає ознакою модерної соціальності. 3 цього часу в пошуках ідентичності людини виникають дві протилежні інтенції: з одного боку, розширення життєвого простору власної свободи, а з іншого, - винайдення іiї меж.

3 цього приводу цікавою, на нашу думку, є висловлювання С.Жижека щодо правлячих ідей, які не є ідеями тих, хто править [5, 230-231]. Так, для соціальності модерного суспільства, за умови iii початкового стану, залишаються актуальними прагнення солідарності, як віддаленого відчуття первинної соціальності та народні сподівання на істинну спільноту. Певний час для того, щоб правляча ідеологія могла управляти більшістю, вона має інкорпорувати ці народні сподівання або своєрідні їх викривлення, які відображають інтереси домінуючих сил. Так, Ж. Дельоз і Ф.Гваттарі називають фашизм перверсією стадного бажання, тобто він не був обманом мас - люди цього хотіли. Тому слід знайти відповідь на питання: Чому після революцій, боротьби за права та свободи, в період індивідуалізації виникає бажання рабства? У пошуках відповіді автори посилаються на міркування Б.Спінози, В.Райха щодо прагнення 
рабства як порятунку, що є фундаментальною проблемою соціальної філософії. На думку 3.Баумана, соціологія взагалі від свого початку більше вивчає проблему несвободи, ніж свободи [10]. Ж.Дельоз і Ф.Гваттарі формулюють вихідне положення свого бачення соціальної філософії як існування лише бажання і соціальності, наголошуючи на їх єдності суспільного виробництва та продукування бажання. 3 іншого боку, форма суспільного виробництва пригнічує продукування бажання, а виробництво бажання має ресурс для того, щоб підірвати соціальну форму [3].

Щоб уникнути руйнування створених соціальних форм, в період пізнього модерну виникає образ Паноптикуму (Дж.Бентам), який в XX ст. здобуває не лише філософські (М.Фуко, 3.Бауман), літературні (Є.Замятін, Дж.Оруел) рефлексії, а й практичні втілення (в’язниця Пресідіо Модело). Ж.Дельоз і Ф.Гваттарі називають капіталізм безмежною жорстокістю, гіршою за первісну залежність i терор деспота, оскільки в його центрі перебуває зона надексплуатації, а на периферії - жорстокі форми експлуатації. Так, автори називають в'язницю не метафорою заводу, а тим, чим є завод [3]. Тобто поступово із меж природи і первісних спільнот модерну людина потрапляє в межі соціальної організації життя, соціальних інститутів.

Соціальні межі інститутів підтримуються страхом, який $\epsilon$ продуктом розвинутого модерну і який може перетворити сучасний крайній індивідуалізм на його екстремальну протилежність. Серед усіх людських страхів суто новочасні, на думку 3.Баумана, виникли за «першої дерегуляції-з-індивідуалізацією», коли міцно закорінені у давні вузли спільнот і корпорацій міжлюдські відносини виявилися послабленими або розірваними [2, 103]. Необхідно було пошкоджені природні зв'язки замінити на їх штучні еквіваленти - спілки, асоціації, колективи, - приналежність до яких мала замінити традиційну солідарність. Для цього було застосовано новочасний спосіб керування страхом, коли штучна солідарність убезпечувала від небезпек. Але попри інтенсивне зближення, люди часто залишались відокремленими один від одного або просто рабами збурення людської маси, стандартизованої на заводі [13]. Зображення подібного стану соціальності можна знайти у метафорі Шопенгауера про дикобразів, які притискаються один до одного, щоб зігрітися, але не забувають розправити голки, щоб тримати дистанцію.

Сьогодні розпад цієї штучної солідарності є симптомом кінця модерного способу керування людьми за допомогою страху, симп- 
томом другої стадії дерегуляції-з-індивідуалізацією [2, 103]. Цю тенденцію до роз'єднання уловив А. Токвіль. Аналізуючи його роботи, сучасні дослідники спиняються на ідеї тілесного роз'єднання демократичного суспільства. Якщо для голістичних суспільств творення тіла (традиційних, тоталітарних) характерною є єдність людини як із самою собою, так і з іншими, то для демократичних характерні взаємообернені паралельні процеси роз'єднання колективного й індивідуального. Тобто демократичне суспільство після тілесного самороз'єднання, яке може призвести до «роз-творення», має перетворити тіло або заповнити цінностями, утопічними очікуваннями, надати змісту наявному спорожнілому соціальному тілу, творити історичність [9, 89-91].

В спорожнілому соціальному тілі формується модерний консерватизм, який суттєво відрізняється від традиціоналізму тим, що базується на досвіді зникнення традиційних цінностей та авторитетів. 3 точки зору модерного консерватизму, не існує універсально прийнятих референційних рамок. С.Жижек описав модерний парадокс, який випливає з відмінності між принципом порядку та конкретним порядком. На його думку, не існує способу уникнути формалізму в межах модерну $[5,147]$.

Самих спроб змінювати модерн було багато. Хитрістю модерну назвав В.Срмоленко антимодерний модерн, який «час від часу повертає до минулого, аби самому оновитися та не стати традицією» [4]. Відбувалась модернізація щодо самої себе, проходячи через ряд біфуркацій. Прагнення нового загострювало ностальгію за минулим, модернізаційні проекти викликали антимодерні рухи.

Починаючи від Просвітництва, кризи модерну припадали на початок століть, після чого наступала доба спроб суперечливого синтезу модерного світобачення з антимодерними симпатіями, поєднуючи ідеал поступу з мрією про повернення до глибинного минулого [4]. Така періодичність і взаємозв'язок у ХX ст. викликають сумніви щодо однозначності розмежування та протиставлення модерну та антимодерну, їх раціональності та ірраціональності, продукуючи різні варіанти діалогу, нових філософських форм, концепцій (В.Беньямін, А.Бергсон, Р.Каюа, Р.Генон, О.Шпенглер, Ж. Еллюль, П. Тейяр де Шарден та ін.). В.Срмоленко в понятті антимодерного модерну концептуалізує парадоксальність самозаперечення модерну. Дослідник вирізняє два його типи: «консервативну революцію», як повернення до істини в справжнє минуле через 
революційний стрибок у майбутнє, та «революційну містику», як рух до істини «інтегральної» людини у майбутнє через містичний стрибок у минуле до домодерних ідеалів [4].

Сьогодні, розглядаючи модерн, дослідники часто уточнюють, про які саме періоди, властивості модерності йдеться. Все частіше використовуються поняття «домодерн», «премодерн», «модерн», «антимодерн», «антимодерний модерн», «контрмодерн», «квазімодерн», «постмодерн» і т.ін., коли рух уперед відбувається у різний, часом парадоксальний спосіб.

Представники антиновочасності, сприймаючи як невідворотну катастрофу те, що сталося з модерним раціоналізованим і розчавленим світом, бачать, що соціальне населене холодними і раціональними монстрами, а доновочасний космос остаточно трансформувався у механічне поєднання чистих матерій. На думку Б. Латура, новочасні і антиновочасні мають однакові погляди щодо ситуації, яка склалася, але оцінюють ії з протилежних позицій, тобто постмодерністи погоджуються із антиновочасними, що йдеться про катастрофу, але інтерпретують іï як позитив, привід для радості [6, 202-203].

Антиновочасна реакційність щодо модерного світосприйняття буває, на думку Б. Латура, двох типів. Перший тип - не потрібно прагнути покінчити 3 пануванням людини над людиною. Другий не потрібно прагнути покінчити з пануванням над природою [6, 69]. Б. Латур зазначає, що завжди співіснують дві сукупності практик: практики змішування, що створюють мережі, гібриди природи i культури, і практики критики, очищення, що відокремлюють онтологічну зону людей від «не-людей» $[6,71]$. Новочасний тип мислення визнає пріоритетним критичне очищення. Людина перестає бути новочасною тоді, коли водночас спрямовує свою увагу на очищення і гібридизації, змінюючи теперішнє, майбутнє і навіть минуле, змінюючи погляд на нього. Саме тому Б. Латур і робить висновок, що з цієї позиції Нового часу не було.

Інші особливості домодерного, антимодерного і модерного мислення відзначає В.Срмоленко. Модерне мислення шукає в речах і особах ідентичності, вимагає тотожності з собою. Домодерне i антимодерне мислення розглядають речі, індивідів як такі, що відтворюються через повторення, уподібнення, регенеруючи таким чином інші речі, індивідів, часи. Сама схильність до уподібнення $\epsilon$ складовою і домодерного, і (приховано) модерного мислення. Доказом цього є мода, світ імітації [4]. 
Буржуазне суспільство позиціонує свої вимоги до людини як до автентичної і самобутньої особистості, надаючи пріоритет іiі індивідуальним якостям, а не становими. Прикметою сьогодення $\epsilon$ розпад єдиної ідентичності, такої, що організує навколо себе раціональну соціальну систему, та пошук ії нових форм [8]. Ще однією реакцією на процес індивідуалізації, за В.В.Ляхом, є руйнація мережевим суспільством, в якому наперед виходить колективна ідентичність, нове колективне «Я», формуються ідентичності мережевого суспільства. Тоді як традиційні ідентичності стають полем для формування різних форм фундаменталізму. Хоча ідентичності змінюються відповідно до вимог часу, ці зміни відбуваються у напрямку від більш сталих до менш тривких [7]. При індивідуалізації відбувається поворот від безпосередніх «мережевих», «зв'язкових» до «категоричних» ідентичностей $[12,338]$, від колективних патріархальних - до індивідуалізованих. Відповідно традиційні сімейні, релігійні ідентичності в індустріальному суспільстві втрачають своє значення і відходять на другий план [7]. Людина стає більш незалежно мислячою, більш вільною, вона живе наповнено, орієнтуючись на себе, хоча і стає більш самотньою. Як зазначає В.В. Лях, самотність та ізоляція $є$ платою за свободу в індустріальному суспільстві, коли люди набувають незалежності та стають більш вільними [7].

Однією з актуальних дихотомій соціальної філософії є протиставлення комунітаризму та лібералізму з їх аксіологічними моделями домінування у виборі, формуванні цінностей, ідентичностей спільноти чи індивіда. Посилаючись на аналіз дилеми комунітаризму та лібералізму, здійснений Л.А.Ситніченко [11], спинимося на згаданих ідеях деяких сучасних авторів. Зокрема, Ч.Тейлор [9] таких авторів означив: 1) як атомістів, для яких пріоритетними є індивідуальні права, а суспільні дії й блага є властивостями особистостей та їх благ; та 2) голістів, для яких пріоритетними є осмислення солідарності і приналежність до спільноти та цінність колективного блага, взаємної довіри, поваги. В добре організованому суспільстві Дж.Роулз [14] вбачає те, що заохочує до самостійності громадян, до пошуку об'єктивної справедливості. Щодо спільнот, то автор вирізняє два їх типи: прагматичне об'єднання незалежних індивідів 3 протилежними інтересами і об'єднання людей, які прагнуть спільної мети та мають певні спільні цінності. Абстрактна дилема індивіда та спільноти розв'язується через реальну людську солідарність, через визнання. 
Отже, індивідуалізм стає моральною засадою модерного суспільства і викликає суперечки щодо своєї цінності. Сучасні автори (А.Гонет, Р.Форст, Ш.Гозепат, Е.Гутман, М.Сендел, Дж.Роулз, Ч. Тейлор, Л.А.Ситніченко, В.В.Лях та ін.), які аналізували доречність протиставлення індивідуального та соціального, шукають варіанти поєднання простору вільної особистості та солідарного суспільства, розглядають інтерсуб'єктивність як вимір людського буття, самовизначення людини в межах спільноти, їх розуміння справедливості та їі вкоріненості в суспільну мораль як спільне благо [11].

У філософських рефлексіях пізнього модерну ідея індивідуалізму дістає полярні оцінки і викликає протилежні відчуття. Так, у християнській філософії (П.Тейяр де Шарден, Ч.Тейлор) модерний індивідуалізм розглядається як моральна ідея, а не як відокремлення індивіда чи «обраних рас», яке П.Тейяр де Шарден, назвав глухим кутом, якого необхідно уникнути. Для конструктивного індивідуалізму властиво, за Ч.Тейлором, «уявлення себе як такого, що належить до ширших і більш безособових спільнот: держави, руху, людства як цілого» $[12,338]$.

Інакше, застерігає П.Тейяр де Шарден, людство може досягнути кульмінації в множині активних, дисоційованих точок, які шукають порятунку в доведеній до надмірності індивідуалізації [13]. Якщо подібний варіант влаштовує когось із модерно або постмодерно орієнтованих філософів, то для традиціоналістської антимодерної позиції він більш схожий на патологію, ніж на норму. Еволюція зростання свідомості вбачається ними в дії до єднання, коли кожний може розвиватися зі всіма іншими і через них, а з часом - об'єднатися в організоване ціле, коли соціальні зв'язки матимуть гіперорганічну природу. 3 такої позиції, озвученої П.Тейяром де Шарденом, чим більше людина наближається до інших, тим більше стає собою, відрізняється від інших, тобто здійснюється диференційована єдність, персоналізація цілого і персоналізація елементів. Прагнучи до відокремлення, людина індивідуалізується, проте, вершиною є особистість, яка стає такою в об'єднанні з іншими. В такому випадку людина сама свідомо обирає спільноту, до якої прагне приєднатися, в суспільні процеси якої прагне включитися. Подібна свобода $є$ постійним процесом вибору, визначення меж особистості, iї спільноти та суспільства з узгодженням відповідальності, прав та обов'язків.

Такий висновок П. Тейяра де Шардена випливає 3 його загальної тези про еволюцію людини і ноосфери в цілому. Тому «матерія» 
соціальності та іiі видозміни не є предметом його розгляду.

Аналіз опозиції між лібералізмом та комунітаризмом представлений в працях Л.А.Ситніченко [11]. На іï думку, лібералізм має критично переглянути свою модель людини, врахувати значення солідарності, створити універсальне поле, яке опосередковуватиме взаємозв'язок індивіда й спільноти, спільного буття, спільний його інтерсуб'єктивний вимір. I навпаки: комунітаристи мають звернути увагу на парадоксальність традиційних відносин, за яким чим більше індивід стає залежним від спільноти, тим більше зростає його відчуження, виникає ворожість до людей, зникає індивідуальна відповідальність, маскуючись колективною.

Отже, описи контексту модерних та антимодерних трансформацій соціальності свідчать, що нелінійний розвиток модерної соціальності відбувається через етапи збурень і сталості. Між двома біфуркційними точками розвитку суспільства основні системоутворювальні фактори соціальності сприймаються як сталості, що самооновлюються. В ці періоди соціальність сприймається як «традиційна», «класична». В періоди ж чергового революційного оновлення вона посилається на надбання попереднього збурення і вступає в полеміку 3 ним. В сучасному контексті соціальність більше визначається не часом, а станом свідомості кожної окремої особистості та суспільства. Хоча слід зважати і на парадигмальні зміни в соціальності, що пов'язані з переходом від модерну до постмодерну.

\section{ЛІТЕРАТУРА}

1. Бауман 3. Индивидуализированное общество. - М., 2005. - 390 с.

2. Бауман 3. Плинні часи: життя в добу непевності. - К., 2013. - 176 с.

3.Делёз Ж., Гваттари Ф. Анти-Эдип: Капитализм и шизофрения. - Екатеринбург, 2007. $-672 \mathrm{c}$.

4. Срмоленко В.А. Модерн та антимодерн у філософії культури Вальтера Беньяміна: автореф. дис. на здобуття наук. ступеня канд. філос. наук: спец. 09.00.04 «філософська антропологія, філософія культури». - К., 2008. -20 c.

5. Жижек С. Дражливий суб'єкт: відсутній центр політичної онтології. К., 2008. $-510 \mathrm{c}$.

6. Латур Б. Нового Времени не было. Эссе по симметричной антропологии. - СПб., 2006. -240 с.

7. Лях В.В. Свобода і пошук нових форм ідентичності в добу глобаліза- 
ції // Мультиверсум. Філософський альманах. - К., 2006. - №57.

8. Лях B.B. Соціальний характер людини і проблема ідентичності в добу глобалізації // Мультиверсум. Філософський альманах. - К., 2011.№9 (107). - C.3-26.

9. Тейлор Ч. Непорозуміння: дебати між лібералами та комунітаристами // Сучасна політична філософія. - К., 1998. - С. 544-575.

10. Бауман 3. Свобода. - М., 2006.

11. Ситніченко Л.А. Універсальні та особливі виміри загальнолюдських цінностей в сучасній політичній філософії // Обгрунтування цінностей: сучасні філософські дискурси. - К., 2016.

12. Тейлор Ч. Секулярна доба. Книга перша. - К., 2013. - 664 с.

13. Тейяр де Шарден П. Феномен человека. - М., 1987. - 240 с.

14. Ролз Дж. Теорія справедливості. - К., 2001. - 822 с.

Лукашенко М.В. Модерний тип соиіальності: між минулим і належним.

Трансформації соціальності як особливого виміру буття людини набувають самобутніх властивостей у суспільствах пізнього модерну, в період визначених класових та гендерних меж. У статті увага зосереджується на полеміці модерну з минулим і належним, на особливостях змін соціальності в контексті модерних та антимодерних рухів. Революційні зміни соціальності розглядаються крізь призму опозиції індивідуального і загального, модерного консерватизму і традиціоналізму. Специфічно модерними рисами соціальності $\epsilon$ індивідуалізація та пошук ідентичності, які визначаються законами класу, приналежність до якого необхідно постійно підтверджувати. Модерній індивідуалізації протиставляється антимодерна особистість, яка набувається в об'єднанні з іншими. Модернізм характеризується як тенденцією до роз'єднання, так і прагненням до солідарності, що наповнює соціальне буття утопічними очікуваннями або ностальгією за минулим.

Ключові слова: модерн, антимодерн, соціальність, індивідуалізація, ідентичність.

Лукашенко М.В. Модерный тип сочиильности: между прошльм и должествующим.

В статье раскрываются революционные изменения социальности в период позднего модерна в контексте оппозиции индивидуального и общественного; модерного консерватизма и традиционализма; модерной и антимодерной социальности. Специфически модерной социальностью является индивидуализация, которая определяется законами класса, принадлежность к которому необходимо постоянно подтверждать. Модерной индивидуализации противопоставляется антимодерная личность, которая 
формируется в единении с другими. Модернизм характеризуется как тенденцией к разъединению, так и стремлением к солидарности, что наполняет социальное бытие утопическими ожиданиями или ностальгией за прошлым.

Ключевые слова: модерн, антимодерн, социальность, индивидуализация, идентичность.

Lukashenko M.V. The modern type of sociality: between past and oughtness. The article reveals revolutionary changes in sociality implemented in the period of the late modernity in the context of opposition of individual and social; modern conservatism and traditionalism; anti-modern and modern sociality. Individualization is a specifically-modern sociality. It is determined by the laws of the class, identity to which ought to be constantly confirmed. The modern individualization is opposed to an anti-modern personality that is developed in unity with others. Modernism is characterized with the tendency for separation, and also with the aspiration for solidarity filling social being with millenarian expectations and wistfulness for the past.

Key words: modernity, anti-modernity, sociality, individualization, identity. 